\title{
Pengaruh Good Corporate Governance dan Corporate Social Responsibility Terhadap Kinerja Keuangan pada Perusahaan Keuangan di Bursa Efek Indonesia
}

\author{
Rodhiyani Cahya Ningsih ${ }^{1}$ \\ 1)rodhiyanicahya07@gmail.com \\ Dian Retnaningdiah ${ }^{2}$ \\ 2)dianretnaningdiah@unisayogya.ac.id \\ Fakultas Ekonomi, Ilmu Sosial dan Humaniora \\ Universitas 'Aisyiyah Yogyakarta
}

\begin{abstract}
This study was to determine the effect of Good Corporate Governance (GCG) and Corporate Social Responsibility (CSR) on Financial Performance as measured by Return on Assets (ROA) in financial companies listed on the IDX in the period of 2014-2018. This study used a Multiple Linear Regression Analysis. The independent variable of the research used GCG as proxied by the Board of Directors, Proportion of Independent Commissioners, Managerial Ownership, Institutional Ownership, and the Audit Committee, while CSR is measured using indicators based on the 2016 Global Reporting Inititive (GRI) Standard. Financial performance as measured by Return on Assets (ROA). Sampling data using purposive sampling, and there are 11 companies that meet predetermined criteria. This study showed that the Managerial Ownership has an effect on Financial Performance (ROA). This is shown as hypothesized. The Board of Directors, the Proportion of Independent Commissioners, Institutional Ownership, the Audit Committee do not affect the Financial Performance (ROA), this is not as hypothesized. CSR has no effect on Financial Performance (ROA), this is not what was hypothesized. The Board of Directors, Proportion of Independent Commissioners, Managerial Ownership, Institutional Ownership, Audit Committee and CSR simultaneously affect Financial Performance (ROA). These results meet the hypotheses of the study.
\end{abstract}

Keywords: Good Corporate Governance, Corporate Social Responsibility, Financial Performance

\section{PENDAHULUAN}

Berkembangnya ilmu pengetahuan dan teknologi yang ditandai dengan semakin berkembang pula dunia bisnis mengakibatkan persaingan yang semakin pesat. Semakin majunya suatu perusahaan kesenjangan sosial dan kerusakan lingkungan semakin tinggi. Perusahaan yang baik tidak hanya memikirkan bagaimana menghasilkan laba yang 


\section{Rodhiyani Cahya Ningsih, Dian Retnaningdiah}

besar, melainkan juga memiliki keperdulian terhadap lingkungan, dan kesejahteraan masyarakat serta mempertahankan tata kelola perusahaan yang baik. Keberhasilan suatu perusahaan dalam dunia bisnis ditentukan oleh kontribusi perusahaan terhadap keperduliannya pada kesejahteraan masyarakat. Tanggungajawab sosial telah menjadi hal yang sangat lazim dilakukan dibeberapa negara. Tanggung jawab sosial merupakan suatu iktikad baik perusahaan dalam menjaga hubungan baik terhadap stakeholder maupun masyarakat yang berada sekitar lingkungan perusahaan.

Corporate Social Responsibility (CSR) ialah suatu gerakan perusahaan yang menjadi salah satu investasi dalam waktu jangka panjang dan juga memberikan keuntungan bagi masyarakat. CSR merupakan bentuk dari tanggungjawab yang dilakukan oleh perusahaan dalam memperbaiki masalah yang diakibatkan dari aktivitas operasional perusahaan seperti masalah sosial dan lingkungan, maka dari itu CSR memiliki peran untuk meningkatkan nilai suatu perusahaan (Sari, 2018). Perusahaan dapat menciptakan citra baik sehingga menimbulkan penilaian positif dari masingmasing pemangku kepentingan dalam perusahaan. CSR penerapannya diungkapkan dalam laporan tahunan (annual report) yang dapat meningkatkan nilai perusahaan dimata investor. Dan juga Good Corporate Governance (GCG) telah menjadi kebutuhan bagi semua perusahaan. CSR adalah konsekuensi dari pelaksanaan konsep GCG dalam praktik dan penerapannya. Pada prinsipnya perusahaan perlu memperhatikan lebih kepentingan stakeholder - nya, sesuai dengan aturan yang ada dalam menjalin kerjasama yang aktif dengan stakeholder, demi kelangsungan hidup jangka panjang perusahaan (Fauzi, Surasni dan Alamsyah, 2016).

Sustainability reporting atau laporan berkelanjutan adalah laporan CSR yang dilakukan oleh perusahaan untuk mengukur dan mengungkapkan, serta upaya perusahaan untuk menjadi perusahaan yang akuntabel bagi seluruh pemangku kepentingan (stakeholders) bertujuan untuk keikutsertaan perusahaan menuju pembangunan yang berkelanjutan. Laporan ini juga memuat kinerja perusahaan dalam tiga aspek, yakni ekonomi, lingkungan dan sosial. Tujuan dibuatnya laporan ini untuk menjadi penilaian suatu perusahaan apa sudah mampu untuk melaksakan sistem berkelanjutan (Sari dan Devi, 2019).

Penelitian ini dilakukan dengan mencari data yang berada di Bursa Efek Indonesia (BEI), dengan memfokuskan pada perusahaan sektor keuangan. Alasan kenapa memilih sektor keuangan karena masih sedikitnya penelitian yang membahas Good Corporate Governance (GCG) dan Corporate Social Responsibility (CSR) pada perusahaan keuangan. Beberapa bahkan kebanyakan penelitian terdahulu memilih sampel perusahaan manufaktur.

Penelitian ini dilakukan untuk membuktikan adakah pengaruh dari Good Corporate Governance (GCG) dan Corporate Social Responsibility (CSR) terhadap kinerja keuangan khususnya pada perusahaan keuangan. Meskipun penelitian ini telah cukup banyak dilakukan, akan tetapi hasil dari penelitian-penelitian yang telah dilakukan tersebut berbeda-beda. Dan dari penelitian terdahulu dengan penelitian sekarang terdapat 
perbedaan mengenai sampel dan penggabungan beberapa metode analisis data dari penelitian-penelitian terdahulu. Penelitian terdahulu lebih banyak yang mengambil perusahaan manufaktur dan atau perusahaan keseluruhan di BEI.

Berdasarkan latar belakang diatas, penulis mengambil judul Pengaruh Good Corporate Governance dan Corporate Social Responsibility terhadap Kinerja Keuangan Pada Perusahaan Keuangan Yang Terdaftar di Bursa Efek Indonesia (BEI), untuk mengetahui dampak atau pengaruh dari Good Corporate Governance (CSR) dan Corporate Social Responsibility (GCG) terhadap kinerja keuangan perusahaan.

\section{KAJIAN LITERATUR DAN TEORI}

\section{Good Corporate Governance (GCG)}

GCG pertama kali dikenalkan di Indonesia oleh IMF (International Monetary Funds) dalam rangka pemulihan ekonomi pasca krisis. Krisis yang melanda Asia Timur pada saat itu juga berdampak besar pada Indonesia, salah satu penyebabnya adalah tidak adanya GCG di dalam pengelolaan perusahaan, dalam kajian yang dilakukan oleh Booz-Allen \& Hamilton pada tahun 1998, index good corporate governance Indonesia adalah yang paling rendah dibandingkan dengan negara lain di kawasan tersebut. Kajian tersebut didukung oleh penelitian yang dilakukan oleh McKinsey tahun 1999 yang meneliti tentang praktek GCG pada perusahaan-perusahaan di Indonesia.

Corporate governance adalah rancangan sistem yang bertujuan untuk pengarah dalam pengelolaan perusahaan professional yang berdasarkan pada prinsip-prinsip transparansi, akuntabilitas, tanggungjawab, independen, kewajaran dan kesetaraan. Dalam teorinya melaksanakan corporate governance yang baik dapat meningkatkan kinerja keuangan perusahaan, nilai perusahaan, mengurangi risiko yang mungkin dilakukan oleh dewan komisaris dengan keputusan-keputusan yang menguntungkan diri sendiri dan pada umumnya pelaksanaan corporate governance yang baik dapat meningkatkan kepercayaan investor pada perusahaan (Tjager et al, 2003). Good corporate governance secara definitif merupakan sistem yang mengatur dan mengendalikan perusahaan yang menciptakan nilai tambah (value added) untuk semua stakeholder (Monks, 2003).

Dalam konsep GCG terdapat empat komponen utama (Kaen, 2003; Shaw, 2003) yaitu fairness, transparency, accountability, dan responsibility. Keempat komponen tersebut penting karena penerapan prinsip good corporate governance secara konsisten terbukti dapat meningkatkan kualitas laporan keuangan dan juga dapat menjadi penghambat aktivitas rekayasa kinerja yang mengakibatkan laporan keuangan tidak menggambarkan nilai fundamental perusahaan (Kaihatu, 2006).

a. Fairness (keadilan), yaitu perlakuan yang adil dan setara dalam memenuhi hak-hak stakeholder berdasarkan perjanjian serta peraturan perundangan yang berlaku (Kaihatu, 2006). 
b. Transparency (Transparasi/Katerbukaan informasi), Dalam Keputusan Menteri Negara BUMN tahun 2002 mengartikan transparansi merupakan keterbukaan dalam melaksanakan proses pengambilan keputusan dan keterbukaan dalam mengemukakan informasi materiil dan relevan mengenai perusahaan.

c. Accountability (Akuntabilitas), ialah kejelasan fungsi, struktur, sistem dan pertanggungjawaban dalam perusahaan, sehingga pengelolaan perusahaan dapat terlaksana secara efektif dan efisien (Kaihatu, 2006). Jika akuntabilitas diterapkan secara efektif, maka adanya kejelasan dari fungsi, hak, kewajiban, wewenang dan tanggungjawab antara pemegang saham, dewan komisaris serta direksi.

d. Responsibility (Responsibilitas/Pertanggungjawaban), adalah kesesuaian (kepatuhan) dalam pengelolaan perusahaan terhadap prinsip korporasi yang sehat serta taat peraturan perundangan yang berlaku (Kaihatu, 2006). Organization for Economic Cooperation and Development (OECD) menyatakan bahwa prinsip tanggung jawab ini menekankan pada adanya sistem yang jelas untuk mengatur mekanisme pertanggungjawaban perusahaan kepada shareholder dan stakeholder.

\section{Corporate Social Responsibility (CSR)}

CSR dipahami sabagai cara perusahaan mengintegrasikan antara sosial, lingkungan dan ekonomi dalam nilai-nilai budaya, strategi, dan operasi perusahaan secara transparan dan akuntabel. Dengan demikian menghasilkan praktik yang lebih baik dalam perusahaan juga dalam bertindak secara bertanggungjawab terhadap masyarakat dapat membantu membangun nilai bagi perusahaan dan pemegang saham. Trinidads \& Tobacco Bureau of Standards menngartikan bahwa CSR merupakan komitmen usaha untuk terus bertindak etis, beroperasi secara legal, dan berkontribusi untuk peningkatan ekonomi, bersamaan dengan peningkatan kualitas hidup dari karyawan dan keluarganya sekaligus juga peningkatan komunitas lokal, dan masyarakat secara luas.

World Bank memandang CSR sebagai "The commitment of business to contribute to sustainable economic development working with employees and their representatives the local community and society at large to improve quality of life, in ways that are both good for business and good for development". komitmen bisnis untuk berkontribusi dalam pembangunan ekonomi berkelanjutan bekerjasama dengan para pegawai dan melibatkan komunitas lokal serta masyarakat luas untuk meningkatkan kualitas hidup dengan cara yang baik untuk bisnis dan pengembangan.

Konsep CSR dalam pengaplikasiannya di dasarkan pada prinsip-prinsip yang terstandarisasi oleh perkembangan usaha dunia dan organisasi pemerhati lingkungan hidup dunia. Dari tahun 1995, beberapa standar dan code of conduct muncul dengan tujuan untuk menjadi panduan bagi praktik CSR perusahaan. Satu dari standarisasi Corporate Social Responsibility adalah Global Reporting Initiative (GRI). GRI adalah institusi independen yang memiliki misi mengembangkan dan menyebarluaskan panduan pelaporan keberlanjutan (Sustainability Reporting Guideline) yang aplikatif. Institusi ini digagas oleh PBB dan UNEP pada tahun 1997 (Rusdianto, 2003:10). 


\section{Kinerja Keuangan}

Kinerja keuangan ialah analisis yang dilakukan yang bertujuan untuk melihat bahwa perusahaan telah mengunakan aturan pelaksanaan keuangan secara benar (Fahmi, 2014:2). Menurut Fahmi (2012), Kinerja keuangan adalah suatu analisis yang dilakukan untuk melihat sejauh mana perusahaan telah melaksanakan dengan menggunakan aturanaturan pelaksanaan keuangan secara baik dan benar. Seperti dalam menbuat suatu laporan keuangan yang telah memenuhi standar atau ketentuan dalam SAK (standar akuntansi keuangan) atau GAAP (generally accepted accounting principle) dan lainnya. Kinerja keuangan perusahaan dapat diukur dengan menganalisa dan mengevaluasi laporan keuangan. Sering kali kinerja dan posisi keuangan masa lalu digunakan untuk dasar dalam memprediksi kinerja dan posisi keuangan di masa depan (Setiawan, 2017).

Secara umum ada lima tahapan analisis dalam kinerja keuangan perusahaan (Fahmi, 2012), yaitu :

a. Melakukan review terhadap laporan keuangan dengan tujuan agar laporan keuangan yang sudah dibuat tersebut sesuai dengan penerapan kaidah-kaidah yang berlaku umum dalam dunia akuntansi, sehingga dengan demikian hasil laporan keuangan dapat dipertanggung jawabkan.

b. Melakukan perhitungan yaitu menyesuaikan dengan kondisi permasalahan yang sedang dilakukan sehingga hasil perhitungan tersebut akan memberikan suatu kesimpulan sesuai dengan analisis yang diinginkan.

c. Melakukan perbandingan terhadap hasil hitungan yang telah diperoleh, selanjutnya dilakukan perbandingan hasil hitungan dengan berbagai perusahaan lainnya. Metode yang paling umum digunakan untuk melakukan perbandingan ini ada dua, yaitu : Time series analysis dan Cross sectional approach. Dari penggunaan kedua metode diatas diharapkan dapat menghasilkan satu kesimpulan yang menyatakan bahwa berada dalam kondisi sangat baik,baik sedang/normal, tidak baik dan sangat tidak baik.

d. Melakukan penafsiran terhadap berbagai permasalahan yang ditemukan. Dilakukannya analisis untuk melihat kinerja keuangan perusahaaan setelah melewati ketiga tahapan tersebut,

e. Mencari dan memberikan pemecahan masalah terhadap permasalah yang ditemukan.

\section{Perusahaan Keuangan}

Perusahaan Keuangan merupakan suatu lembaga yang dalam pelaksanaannya memiliki fungsi utama yaitu menyalurkan dana dari pihak yang berlebih kepada pihak yang kekurangan dana. Perusahaan keuangan terbagi menjadi beberapa jenis yaitu sebagai berikut:

a. Bank Komersial, yaitu lembaga penyedia jasa simpanan yang memiliki pinjaman sebagai aset utama dan tabungan sebagai kewajiban utama lainnya. pinjaman komersial meliputi kredit mikro, usaha kecil, usaha menengah dan koperasi. 


\section{Rodhiyani Cahya Ningsih, Dian Retnaningdiah}

b. Perusahaan Asuransi, yaitu perusahaan jasa keuangan yang menjaga individu dan perusahaan dari kejadian buruk yang berisiko dengan menyediakan produk asuransi.

c. Perusahaan Sekuritas dan bank investasi, yaitu perusahaan/lembaga keuangan yang menjadi perantara pedagangan efek dan menjamin sekuritas seta terlibat dalam kegiatan jual beli surat berharga.

d. Perusahaan Pembiayaan, yaitu lembaga/badan usaha yang memberikan pinjaman pada individu dan bisnis seperti sewa guna usaha, pembiayaan konsumen dan piutang.

e. Thrifts, yaitu lembaga yang dananya diperoleh dari simpanan masyarakat. Simpanan tersebut dapat berupa tabungan/pinjaman, savings banks dan credit unions.

f. Reksa dana, yaitu badan usaha/lembaga yang menjadi tempat bagi masyarakat pemodal dalam memghimpun dana yang selanjutnya diinvestasikan dalam portofolio efek. Lembaga ini juga menawarkan rencana simpanan dengan mengakumulasikan tabungan selama bekerja yang akan diambil saat masa pensiun.

Kerangka konsep dalam penelitian ini adalah sebagai berikut:

\section{Gambar 1. Kerangka Konsep}

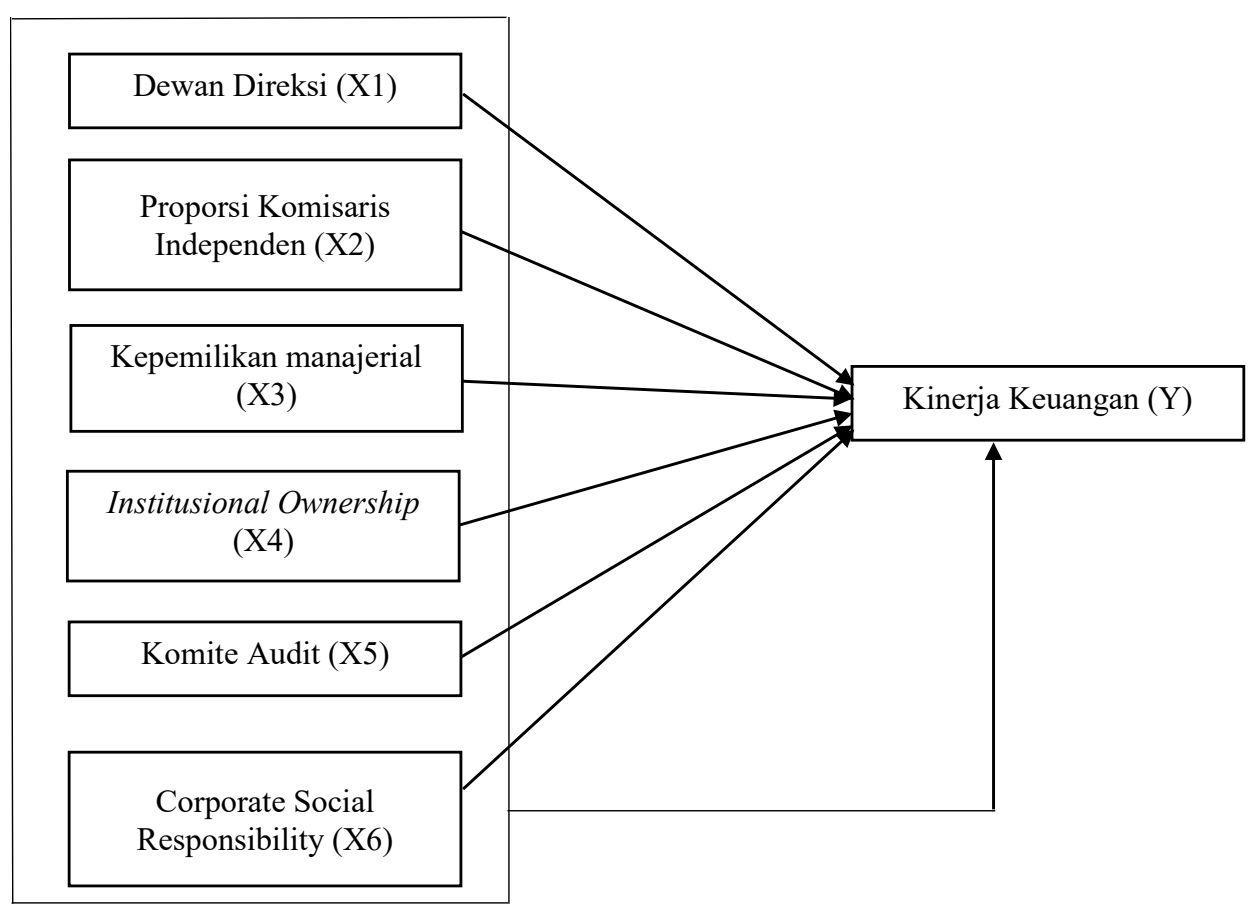

$92 .:$. 


\section{METODE PENELITIAN}

\section{Ruang Lingkup Penelitian}

Penelitian ini merupakan penelitian kuantitatif yang menekankan pada pengujian teori-teori melalui pengukuran variabel-variabel penelitian dengan angka dan melakukan analisis data dengan prosedur statistik. Data penelitian menggunakan data sekunder yang mengacu pada informasi dari pihak lain.

\section{Populasi}

Populasi yang akan diamati adalah seluruh perusahaan keuangan yang terdaftar di Bursa Efek Indonesia (BEI) periode 2014-2018 yaitu berjumlah 91 perusahaan.

\section{Sampel}

Pengambilan sampel menggunakan metode purposive sampling yaitu dimana berdasarkan pada ciri atau kriteria tertentu. Adapun kriteria pengambilan sampel dalam penelitian adalah :

a. Perusahaan keuangan yang terdaftar di BEI periode 2014-2018.

b. Perusahaan yang menerbitkan laporan keuangan yang audited pada tahun 20142018.

c. Perusahaan yang juga menerbitkan laporan keberlanjutan (sustainability report) pada tahun 2014-2018 dengan berpedoman pada GRI.

Jumlah sampel yang memenuhi kriteria yang telah ditentukan diatas adalah sebagai berikut:

Tabel 1. Sampel Penelitian

\begin{tabular}{ccl}
\hline No & Kode Saham & \multicolumn{1}{c}{ Nama Perusahaan } \\
\hline 1 & BBNI & Bank Negara Indonesia (Persero) Tbk \\
2 & BBRI & Bank Rakyat Indonesia (Persero) Tbk \\
3 & BBTN & Bank Tabungan Negara (Persero) Tbk \\
4 & BFIN & BFI Finance Indonesia Tbk \\
5 & BJBR & Bank Pembangunan Daerah Jawa Barat Tbk \\
6 & BJTM & Bank Pembangunan Daerah Jawa Timur Tbk \\
7 & BMRI & Bank Mandiri (Persero) Tbk \\
8 & BNGA & Bank CIMB Niaga Tbk \\
9 & BNII & Bank Maybank Indonesia Tbk \\
10 & BNLI & Bank Permata Tbk \\
11 & NISP & Bank OCBC NISP Tbk \\
\hline
\end{tabular}




\section{Metode Pengumpulan Data}

Pengumpulan data pada penelitian ini dilakukan dengan studi kepustakaan, mengumpulkan dan mencatat data melalui Bursa Efek Indonesia (BEI), Website perusahaan dan juga melalui Website Global Reporting.

\section{Definisi Operasional Variabel Penelitian}

Variabel adalah apapun yang dapat membedakan atau merubah nilai (Uma dan Roger, 2017). Terdapat dua jenis variabel yang digunakan dalam penelitian ini yaitu variabel independen $(\mathrm{X})$ dan variabel dependen $(\mathrm{Y})$.

a. Variabel Independen

1) Good Corporate Governance

Indikator Good Corporate Governance yang digunakan dalam penelitian sebagai berikut :

1) Dewan Direksi

Direksi merupakan organ perseroan yang mempunyai wewenang dan tanggungjawab penuh atas pengurusan perseroan untuk kepentingan perseroan, yang sesuai dengan maksud dan tujuan perseroan (Larasati $\mathrm{dkk}, 2017)$.

2) Proporsi Komisaris Independen

Dewan komisaris mempunyai tugas dan tanggungjawab serta wewenang untuk mengawasi kebijakan dan juga kegiatan yang dilakukan direksi dan manajemen dalam mengelola sumber daya agar berjalan efektif dan efisien dalam mencapai tujuan organisasi, serta memberikan pendapat jika diperlukan (Windarni dkk, 2018).

3) Kepemilikan Manajerial

Kepemilikan manajerial adalah pemegang saham dari pihak manajemen yang mana secara aktif ikut serta dalam pengambilan keputusan perusahaan (Sari dan Priyadi, 2017).

4) Institusional Ownership (Kepemilikan Institusional)

Kepemilikan institusional merupakan saham perusahaan yang dimiliki oleh lembaga yaitu bank, perusahaan asuransi, perusahaan investasi, dan lembaga lainnya (Triastuty dan Riduwan, 2017).

5) Komite Audit

Menurut Surya dan Ivan (2008), komite audit adalah suatu komite yang beranggotakan satu atau lebih anggota komisaris dan keberadaannya terbebas dari pengaruh direksi, eksternal auditor dan hanya bertanggungjawab pada dewan komisaris.

a) Corporate Social Responsibility

$$
C S R I j=\frac{\sum \mathrm{Xij}}{n j}
$$


CSRIj : Corporate Social Responsibility Disclosure Index Perusahaan $\mathrm{j}$

$\mathrm{N} \quad$ : Jumlah item pengungkapan

$\Sigma X i j \quad: 1=$ jika item diungkapkan; $0=$ jika item tidak diungkapkan. Dengan demikian, $0 \leq \mathrm{CSRIj} \leq 1$

\section{b. Variabel Dependen}

Variabel dependen pada penelitian ini adalah Kinerja Keuangan yang diestimasikan melalui Return on Assets (ROA). ROA menggambarkan seberapa besarnya return yang dihasilkan dari uang yang ditanamkan dalam bentuk aset (Murhadi, 2018). Return yang dihasilkan menunjukkan produktivitas seluruh dana perusahaan, baik dari modal sendiri ataupun modal pinjaman. Semakin rendah ROA, semakin tidak baik, dan begitun sebaliknya.

\section{Metode Analisis Data}

Analisis data pada penelitian ini menggunakan Software IBM SPSS Statistics versi 25 . Adapun metode analisis data yang digunakan adalah regresi linear berganda. Tahapan analisis dalam penelitian ini adalah menguji model regresi linear berganda serta mengintepretasi hasil penelitian. Analisis statistik deskriptif serta uji asumsi klasik yang meliputi Uji multikonieritas, autokorelasi, heteroskedatisitas, normalitas, hipotesis dan uji koefisien determinasi $\left(\mathrm{R}^{2}\right)$.

\section{HASIL DAN PEMBAHASAN}

\section{HASIL}

Hasil dari uji asumsi klasik menunjukkan terbebas dari multikonieritas, autokorelasi, heteroskedatisitas dan hasil uji normalitas baik menggunakan P-Plot dan uji Kormogorov-Smirnov menunjukkan terdistribusi normal. Pengujian hipotesis dalam penelitian ini menggunakan alat regresi linear berganda, memberikan hasil nilai koefisien regresi dengan konstanta sebesar $-3,497$. Sedangkan nilai koefisien regresi masing-masing variabel yaitu $-0,247$ dewan direksi, $-0,039$ proporsi komisaris independen, $-0,167$ kepemilikan manajerial, $-0,220$ kepemilikan institusional, $-0,043$ komite audit, dan -0,005 CSR. Dengan demikian model regresi yang dihasilkan adalah sebagai berikut:

ROA $=-3,497-0,247 \mathrm{DD}-0,039 \mathrm{PKI}-0,167 \mathrm{KM}-0,220 \mathrm{KI}-0,043 \mathrm{KA}-0,005 \mathrm{CSR}+\mathrm{e}$

$\begin{array}{lllllll}\text { Sig. t } & :(0,512) & (0,939) & (0,001) & (0,274) & (0,887) & (0,986) \\ \mathrm{t} & :(-0,664) & (-0,007) & (-3,495) & (-1,115) & (-0,143) & (-0,018)\end{array}$

Sig. F $\quad: 0,001$

F : : 4,839

R Square : 0,484

Adj. R Square: 0,384 


\section{PEMBAHASAN}

Berdasarkan pengujian terhadap 11 sample penelitian menunjukkan bahwa variabel independent Good Corporate Governance (GCG) yang diproksikan melalui Dewan Direksi, Proporsi Komisaris Independen, Kepemilikan Institusional, dan Komite Audit menunjukkan hasil penelitian bahwa variabel independen tidak berpengaruh terhadap Kinerja Keuangan (ROA).

Untuk Corporate Social Responsibility (CSR) hasil penelitian menunjukkan bahwa variabel independen Corporate Social Responsibility (CSR) tidak berpengaruh terhadap Kinerja Keuangan (ROA). Dapat dilihat dari nilai signifikansi sebesar 0,986, nilai tersebut lebih besar 0,05 (0,986>0,05). Sedangkan Dewan Direksi, Komisaris Independen, Kepemilikan Manajerial, Institusional Ownership, Komite Audit dan Corporate Social Responsibility Berpengaruh secara simultan terhadap Kinerja Keuangan (ROA). Hasil penelitian menunjukkan variabel independen berpengaruh signifikan terhadap Kinerja Keuangan (ROA). Dapat dilihat dari nilai signifikansi sebesar 0,001, nilai tersebut lebih kecil 0,05 $(0,001<0,05)$.

\section{KESIMPULAN DAN SARAN}

\section{Kesimpulan}

Kesimpulan yang diperoleh dari penelitian ini adalah bahwa GCG yang diproksikan Dewan Direksi, Proporsi Komisaris Independen, Institisional Ownership (Kepemilikan Institusional), Komite Audit tidak berpengaruh terhadap Kinerja Keuangan (ROA). Hasil tersebut menjelaskan bahwa banyak atau sedikitnya variabel independen yang dimiliki perusahaan tidak dapat mempengaruhi kinerja keuangan yang diukur dengan Return on Asset (ROA). Sedangkan Kepemilikan Manajerial berpengaruh terhadap Kinerja Keuangan (ROA).

Untuk CSR tidak berpengaruh terhadap Kinerja Keuangan (ROA). Sedangkan Dewan Direksi, Komisaris Independen, Kepemilikan Manajerial, Institusional Ownership, Komite Audit dan Corporate Social Responsibility secara Simultan berpengaruh signifikan terhadap Kinerja Keuangan (ROA).

\section{Saran}

Melihat dari hasil analisis dalam penelitian ini, beberapa saran yang dapat digunakan sebagai bahan pertimbangan bagi para peneliti selanjutnya yaitu:

1. peneliti selanjutnya dapat memperbanyak sampel dan periode yang digunakan lebih panjang.

2. Dari hasil koefisien determinasi hanya $38,4 \%$ dari variabel dependen yang dapat dijelaskan oleh variabel independen, maka peneliti selanjutnya dapat menggunaan variabel independen selain dalam penelitian ini seperti komite risiko, jumlah rapat dewan direksi, jumlah rapat komite audit, jumlah rapat dewan komisaris, 
jumlah rapat dewan pengawas syariah dan debt to equity (DER).

3. Peneliti selanjutnya dapat menggunakan sektor perusahaan yang sama dengan variabel-variabel yang berbeda atau sebaliknya.

4. Peneliti selanjutnya juga dapat menggunakan GRI Standar terbaru agar terus terjadi pembaharuan dalam suatu penelitian.

\section{DAFTAR PUSTAKA}

Andypratama, Lukas William, dan Ronny H. Mustamu. 2013. Penerapan Prinsip-prinsip Good Corporate Governance Pada Perusahaan keluarga : Studi Deskriptif Pada Distributor Makanan. AGORA Vol. 1 No. 1.

Aprianingsih, Astri. 2016. Pengaruh Penerapan Good Corporate Governance, Struktur Kepemimpinan, dan Ukuran Perusahaan Kinerja Keuangan Perbankan yang aterdaftar di Bursa Efek Indonesia Periode 2011-2014. Skripsi.

Ariantini, I Gusti Ayu, Gede Adi Yuniarta dan Edy Sujana. 2017. Pengaruh Intellectual Capital, Corporate Social Responsibility, dan Good Corporate Governance Terhadap Kinerja Perusahaan (Studi Kasus Pada Perusahaan Manufaktur yang Terdaftar di Bursa Efek Indonesia Tahun 2011-2015). e-Journal Sl Ak Universitas Pendidikan Ganesha Jurusan Akuntansi Program S1 Vol. 7 No. 1.

Barus, Ivana Nisa Esterlin. 2016. Pengaruh GCG terhadap Kinerja Keuangan dengan CSR sebagai Pemoderasi di Perusahaan Pertambangan. Jurnal Manajemen dan Keuangan Vol. 5 No.1.

Bastian, Indra. 2006. Akuntansi Sekor Publik: Suara Pengantar. Jakarta: Erlangga

Brigham. E, dan Houston. J. 2006. Dasar-Dasar Manajemen Keuangan. Edisi Kesepuluh. Jakarta: Salemba Empat.

Darmawan, Aldy, Deannes Isynuwardhana, S.E.,M.M2 dan Dewa Putra Khrisna Mahardika, S.E.,M.Si.. 2018. Pengaruh Good Corporate Governance dan Corprate Social Responsibility Terhadap Kinerja Keuangan Perusahaan (Studi Pada Perusahaan yang Terdaftar Secara Berkelanjutan di Corprate Social Responsibility Index (CGPI) Periode 2013-2015). E-Proceeding of Management Vol. 5 No. 1.

Djazilah, Rachma. 2016. Pengaruh Mekanisme GCG dan Pengungkapan CSR Terhadap Kinerja Keuangan. Jurnal Ilmu dan Riset Akuntansi Vol. 5 No. 10.

Fadilah, Firda Hasnah dan Khairunnisa, S.E., M.M. 2018. Pengaruh Good Corporate Governance dan Corporate Social Responsibility Terhadap Kinerja Keuangan Perbankan (Studi Pada Bank Umum Swasta Nasional dan Bank Umun Milik Negara yang Terdaftar di BEI Tahun 2013-2016). e-Proceeding of Management Vol. 5 No.3. 


\section{Rodhiyani Cahya Ningsih, Dian Retnaningdiah}

Fadillah, Adil Ridlo. 2017. Analisis Pengaruh Dewan Komisaris Independen, Kepemilikan Manajerial dan Kepemilikan Institusional terhadap Kinerja Perusahaan yang terdaftar di LQ45. Jurnal Akuntansi Vol. 12 No. 1

Fahmi, Irham. 2012. Analisis Kinerja keuangan. Bandung: Alfabeta.

Fahmi, Irham. 2014. Analisis Kinerja keuangan Panduan bagi Akademisi, Manajer dan Investor untuk Menilai dan Masyarakat Bisnis dari Aspek Keuangan. Bandung: Alfabeta.

Fanani, Zaenal. 2016. Corporate Social Responsibility Di Indonesia. Malang: Intelegensi Media.

Firdausi, Farah, Ibrahim Musa, dan Nyoria Anggraeni Mersa. 2018. Pengaruh Corprate Social Responsibility Terhadap Kinerja Keuangan Pada Bank Pembangunan Daerah Kalimtara. Jurnal Akuntansi Multi Dimensi (JAMDI) Vol. 1 No. 1.

Gantino, Rilla. 2016. Pengaruh Corporate Social Responsibility Terhadap Kinerja Keuangan Perusahaan Manufaktur yang Terdaftar di Bursa Efek Indonesia Periode 2008-2014. Jurnal Dinamika Akuntansi dan Bisnis (JDAB) Vol. 3(2).

Ghozali, Imam. (2018). Aplikasi Analisis Multivariate Dengan Program IBM SPSS 25 Edisi 9. Semarang: Badan Penerbitan Universitas Diponegoro.

Joesmana, Windy Amadhea. 2017. Pengaruh Corporate Sosial Responsibility dan Good Corporate Governance terhadap Kinerja Keuangan (Studi pada Sektor Pertambangan yang Terdaftar di BEI 2013-2015). Artikel Ilmiah.

Kaen, Fred R. 2003. A Blueprint for Corporate Governance: Stregy, Accountability, and the Preservation of Shareholder Value. USA: AMACOM.

Larasati, Shanti, Kartika Hendra Titisari, dan Siti Nurlaela. 2017. Pengaruh Good Corporate Governance Dan Corprate Social Responsibility Terhadap Kinerja Keuangan Perusahaan Manufaktur yang Terhadap di BEI. Seminar Nasional IENACO.

Maksum, Azhar. 2005. Tinjauan Atas Good Corporate Governance di Indonesia. Medan: Gelanggang Mahasiswa, Kampus USU.

Maryanti, Eny, dan Wildah Nihayatul Fithri. 2017. Corporate Social Responsibilty, Good Corporate Governance, Kinerja Lingkungan Terhadap Kinerja Keuangan Dan Pengaruhnya Pada Nilai Perusahaan. Journal Of Accounting Science Vol. 1 No. 1.

Mawarto. 2017. Penerapan Good Corporate Governance (GCG) pada NON Govermental Organization (NGO). Journal of Management and Business Review Vol. 14 No. 1.

Mercuri, Dina, Anggita Langgeng Wijaya, dan M. Agus Sudrajat. 2019. Pengaruh 
Pengungkapan Corprate Social Responsibility Terhadap Kinerja Keuangan Perusahaan (Studi pada seluruh perusahaan BUMN yang terdaftar di BEI periode 2013-2018). Seminar Inovasi Manajemen, Bisnis dan Akuntansi I.

Monks, Robert A.G, dan Minow, N. 2003. Corporate Governance $3^{r d}$ Edition. Blackwell Publishing.

Parengkuan, Winnie Eveline. 2017. Pengaruh Corporate Social Responsibility (CSR)

Terhadap Kinerja Keuangan Perusahaan Manufaktur yang Terdaftar di Bursa Efek Indonesia Melalui Pojok Bursa FEB - UNSRAT. Jurnal EMBA Vol. 5 No. 2.

Rahad, Imam. 2014. Analisis Kinerja Keuangan Perusahaan Berdasarkan Rasio Profitabilitas, Rasio Likuiditas dan Rasio Solvabilitas Pada PT. GoodYear Indonesia Tbk. Skripsi.

Rimardhani, Helfina, R. Rustam Hidayat, dan Dwiantmanto. 2016. Pengaruh Mekanisme Good Corporate Governance Terhadap Profitabilitas Perusahaan (Studi Pada Perusahaan BUMN yang Terdaftar di BEI Tahun 2012-2014). Jurnal Administrasi Bisnis Vol. 31 No. 1.

Rizal, arif. 2016. Pengaruh Corporate Social Responsibility dan Good Corporate Governance Terhadap Kinerja Keuangan Perusahaan (Studi Empiris Pada Perusahaan Pertambangan di Bursa Efek Indonesia). Porsiding Akuntansi Vol. 2 No. 1.

Salamah, Umi. 2019. Pengaruh Islamic Corporate Governance, Islamic Corporate Social Respnsibility dan Reputasi Terhadap Kinerja keuangan Bank Syariah Pada Bank Umum Syariah di Indonesia periode 2011-2017. Skripsi.

Sari, Arum Puspita, dan Priyadi Maswa Patuh. 2017. Pengaruh Intellectual Capital dan Corporate Governance Terhadap Kinerja Perusahaan. Jurnal Ilmu dan Riset Akuntansi Vol. 6 No. 7.

Sari, Kinanti Chandra, dan Devi Farah Azizah. 2019. Pengaruh Corporate Social Responsibility (CSR) Terhadap Kinerja Keuangan Perusahaan (Studi Pada Agrikultur yang Terdaftar di Bursa Efek Indonesia Periode 2016-2018). Jurnal Administrasi Bisnis (JAB) Vol. 73 No. 1.

Sari, Rizki Novita. 2018. Pengaruh Corporate Social Responsibility dan Good Corporate Governance terhadap Nilai Perusahaan dengan Kinerja Keuangan sebagai Variabel Intervening (Studi Pada Perusahaan Indonesia yang Terdaftar di LQ45 Tahun 2013-2016). Skripsi.

Edisi 6 Buku 2. Jakarta: Salemba Empat.

Setiawan, A. Dahyar. 2017. Analisis Kinerja Keuangan Pada PT Rika Rayhan Mandiri. Jurnal Riset Edisi XVIII Vol. 3 No. 007. 
Suciwati, Desak Putu, dan Desak Putu Arie Pradnyan Cening Ardina. 2016. Pengaruh Corporate Social Responsibility Terhadap Kinerja Keuangan (Pada Perusahaan Sektor Pertambangan di BEI Tahun 2010-2013). Jurnal Bisnis Dan Kewirausahaan Vol. 12 No. 2.

Sucipto. 2003. Penilaian Kinerja Keuangan. Jurnal Akuntansi. Universitas Sumatera Utara. Medan.

Triastuty, Siska, dan Ridwan Ahmad. 2017. Pengaruh Modal Intelektual dan Mekanisme Corporate Governance Terhadap Kinerja Keuangan. Jurnal Ilmu dan Riset Akuntansi Vol. 6 No. 2.

Windari, Nunung, Siti Nurlaela, dan Suhendro. 2018. Pengaruh Kepemilikan Institusional, Proporsi Dewan Komisaris Independen, Komite Audit, Pertumbuhan Penjualan dan Leverage Terhadap Tax Avoidance. Seminar Nasional Call For Paper: Manajemen, Akuntansi dan Perbankan.

Wulandri, Ika Sri. 2017. Pengaruh Karakteristik Corporate Governance Terhadap Kinerja Keuangan Pada Bank umum Syariah di Indonesia (Periode 2012-2016). Skripsi.

Yani, Rika. 2016. Analisis Laporan keuangan untuk Menilai Kinerja Keuangan Perusahaan (Studi Pada PT. Asiaplast Industries, Tbk Periode 2009-2014). Skripsi. 